\title{
A multidimensional analysis of marine capture fisheries in China's coastal provinces
}

\author{
Qi Ding ${ }^{1,2} \cdot$ Xiujuan Shan ${ }^{1,2} \cdot$ Xianshi Jin ${ }^{1,2} \cdot$ Harry Gorfine ${ }^{3}$
}

Received: 16 October 2020 / Accepted: 19 March 2021 / Published online: 1 April 2021

(c) The Author(s) 2021

\begin{abstract}
China (herein referred as China's mainland, and excluding Hong Kong, Macau and Taiwan) is the largest contributor to global seafood production. While China's marine fisheries have been extensively documented, there is a gap in systematically quantifying production of its marine fisheries and the different challenges confronting them at the provincial level. We addressed this gap in spatial detail by providing a review that compares and contrasts the exploitation history of China's fisheries at both the national and provincial levels based on official statistical data. We expanded upon this to explore aspects of biosocio-economic challenges faced by the country's 11 fishing provinces. Our analysis suggested that significant increases in domestic marine catches in China have been accompanied by escalating fishing power, which has had differential impacts at the provincial scale. Catch per unit effort (CPUE) sharply declined at both the national and provincial scales, and many traditionally targeted demersal fish stocks showed clear downward trends in terms of catches. The 11 fishing provinces in China can be grouped into four clusters with distinct biological, social, and economic attributes. Targeted measures are recommended accordingly when implementing fisheries management measures for each specific fishing province in order to deliver an overall improvement in the sustainability of China's marine fisheries.
\end{abstract}

Keywords Fishing $\cdot$ CPUE $\cdot$ Demersal $\cdot$ Socioeconomic $\cdot$ Seafood production

\section{Introduction}

China (herein referred to as China's mainland, and excluding Hong Kong, Macau and Taiwan) is the world's largest producer and consumer of fish. In 2018, China's total fisheries production reached 62.2 million tons, representing over one-third of the global fish supply (FAO 2020). Driven by

Xiujuan Shan

shanxj@ysfri.ac.cn

1 Key Laboratory of Sustainable Development of Marine Fisheries, Ministry of Agriculture and Rural Affairs, Shandong Provincial Key Laboratory of Fishery Resources and Ecological Environment, Yellow Sea Fisheries Research Institute, Chinese Academy of Fishery Sciences, Qingdao 266071, China

2 Function Laboratory for Marine Fisheries Science and Food Production Processes, Pilot National Laboratory for Marine Science and Technology (Qingdao), Qingdao 266237, China

3 School of Biosciences, The University of Melbourne, Parkville 3010, Australia growing domestic income and wealth, China consumed 38\% of the global total in 2015 (FAO 2018). Although nowadays aquaculture dominates fisheries production in China, marine capture fisheries remain a significant component of overall supply (Wang and Shi 2015; Zhang 2016; Zhang et al. 2020). Indeed, China ranks as the world's leading fishing nation, accounting for about one-fifth of the global marine catch, of which over $85 \%$ is caught domestically (Normile 2017; Fisheries Bureau of the Ministry of Agriculture and Rural Affairs 2019). Accordingly, studying the development of Chinese marine capture fisheries is germane to gaining a global understanding of the future of wild fish stocks and consequent food security challenges (Blomeyer et al. 2012; Mallory 2016; Szuwalski et al. 2020).

Marine capture fisheries make a significant contribution to domestic food security, create employment, and help sustain the coastal economy in China (Cao et al. 2017; Jin et al. 2015; Teh et al. 2017; Zhang 2018). In 2018, China's marine fisheries employed almost 3.7 million people, of which about one million were professional fishers, and the annual production value of the marine capture fisheries reached RMB 
222.9 billion (US\$ 33.7 billion) (Fisheries Bureau of the Ministry of Agriculture and Rural Affairs 2019). However, decades of intensive exploitation have resulted in emerging issues related to the sustainability of fisheries resources and the health of marine ecosystems (Han 2018; Tang et al. 2016; Szuwalski et al. 2017). China is now facing a reality of declining fish stocks, biodiversity loss, and habitat degradation, which in turn creates challenges in fisheries management and policymaking (Liu and De Mitcheson 2008; Normile 2017; Shen and Heino 2014).

Marine fisheries resources in China are mainly exploited by the country's 11 coastal provinces and municipalities, comprising from north to south Liaoning, Hebei, Tianjin, Shandong, Jiangsu, Shanghai, Zhejiang, Fujian, Guangdong, Guangxi, and Hainan. In addition, there are distinct regional differences in the development patterns of marine fisheries among these coastal areas (Lou et al. 2005; Li et al. 2019; Sun et al. 2016). Understanding the long-term development trends of domestic marine capture fisheries and continued assessment of the performance of each fishing province as it develops is a primary task of policymakers in promoting sustainable development (Liang and Qin 2014; Su et al. 2020).

Past studies have provided a national overview of the developmental history of China's fishing industry (Kang et al. 2018; Xu 2013; Yu and Yu 2008; Zhong and Power 1997). In contrast, fisheries development at the provincial level is comparatively unknown. Given that the developmental history of the fishing industry varies among the country's 11 coastal provinces, understanding the provincial differences in developmental status will contribute to taking corresponding fishery management measures towards sustainable development at the provincial level. Against this backdrop, this study expands upon previous studies to present a more comprehensive and spatially resolved picture about the status of Chinese marine capture fisheries in terms of the triple bottom line of social, economic, and ecological dimensions through the incorporation of previously omitted provincial fisheries data in an integrated multidimensional analysis.

Challenges and threats to sustainability faced by individual fishing provinces depend not only on the exploitation status of fisheries resources but also on the level of coastal community dependence on marine capture fisheries (Garcia and Rosenberg 2010). Fisheries contribute to economies and societies by creating employment, adding economic value, and contributing to food security (Barange et al. 2014). Our study first tracked the trends in domestic marine catches, fishing effort and catch per unit effort, main fish species, catch composition, and fishing gear and vessel size at both the national and provincial levels over recent decades. Based on this detailed information, we further discuss the challenges facing the country's 11 fishing provinces from a biosocio-economic or triple-bottom-line perspective, aiming to offer some propositions on policy implementation for future sustainable fisheries development in China.

\section{Materials and methods}

\section{Data sources}

All fisheries data used in this study were sourced from the China Fishery Statistical Yearbooks (1962-2019). Although the accuracy of catch statistics available from these Yearbooks has been questioned in the past, with suggestions of over-reporting domestic fisheries production, it is also acknowledged that "a more effective statistical system for domestic fisheries has been developed" (Pauly et al. 2014). Indeed, there have been three major adjustments in the China Fishery Statistical Yearbooks throughout this period of years to reduce past inaccuracy and uncertainty in reported catches, accompanied by timely updating of China's fisheries data based on these adjustments in the Food and Agriculture Organization of the United Nation's (FAO) global capture production database. Therefore, all fisheries data used in this study were corrected based on FAO global fisheries landings statistics (www.fao.org/fishery/statistics/en). Detailed revision information about China's fisheries data has been described by its Fisheries Bureau of the Ministry of Agriculture and Rural Affairs (1999).

Data for fish protein intake, total animal protein intake, total employment, GDP, the value of total commodity export, and human population size were obtained from the China Statistical Yearbook (2019), and other associated data were derived from the China Fishery Statistical Yearbooks (1962-2019).

\section{Multidimensional analysis}

Biological, social, and economic indices were used to quantify the threat levels in the 11 fishing provinces (Table 1). The metrics used in the analysis were:

1. Biological-intensive industrial fishing is thought to have profoundly altered the trophic structure of marine ecosystems, with higher trophic level predatory or demersal fish species replaced by smaller, low trophic level fish and invertebrates. Thus, the biological aspect was represented using catch percentages of traditionally targeted demersal fishes and fish species with a trophic level (TL) higher than 3.5. As fishing effort is not reported for individual species in any of the provinces, catch-per-unit-effort was unavailable as a proxy measure of stock biomass, thereby limiting the range of reliable performance metrics available to the two that were chosen for this study. 
Table 1 The average value of bio-socio-economic factors for China and its 11 fishing provinces during 2016-2018

\begin{tabular}{|c|c|c|c|c|c|c|c|}
\hline \multicolumn{2}{|l|}{ Biological } & \multicolumn{3}{|l|}{ Social } & \multicolumn{3}{|l|}{ Economic } \\
\hline $\begin{array}{l}\text { Catch percent- } \\
\text { age of tradi- } \\
\text { tional demersal } \\
\text { fishes }(\%)\end{array}$ & $\begin{array}{l}\text { Catch percent- } \\
\text { age of fish } \\
\text { species with } \\
\text { trophic level } \\
\text { higher than } 3.5 \\
(\%)\end{array}$ & $\begin{array}{l}\text { Food secu- } \\
\text { rity depend- } \\
\text { ency }\end{array}$ & $\begin{array}{l}\text { Ratio of } \\
\text { professional } \\
\text { fisher popula- } \\
\text { tion engaged in } \\
\text { marine fisher- } \\
\text { ies to total } \\
\text { employees (\%) }\end{array}$ & $\begin{array}{l}\text { Percentage of } \\
\text { small-size fish- } \\
\text { ing vessels (by } \\
\text { quantity) (\%) }\end{array}$ & $\begin{array}{l}\text { Domestic } \\
\text { marine catch } \\
\text { as a percent- } \\
\text { age of GDP } \\
(\%)\end{array}$ & $\begin{array}{l}\text { Value of fish- } \\
\text { eries export } \\
\text { as a \% of total } \\
\text { commodity } \\
\text { export }(\%)\end{array}$ & $\begin{array}{l}\text { Per capita } \\
\text { domestic } \\
\text { marine catch } \\
(\mathrm{kg})\end{array}$ \\
\hline 6.5 & 8.6 & 0.03 & 0.02 & 25.5 & 0.1 & 0.1 & 1.9 \\
\hline 11.5 & 11.6 & 0.02 & 0.1 & 50.8 & 0.1 & 0.6 & 3.1 \\
\hline 19.2 & 24.0 & 0.03 & 0.5 & 69.5 & 0.4 & 5.8 & 12.4 \\
\hline 4.9 & 6.2 & 0.03 & 0.03 & 9.6 & 0.02 & 0.1 & 0.6 \\
\hline 19.1 & 21.1 & 0.04 & 0.1 & 39.6 & 0.2 & 0.1 & 6.5 \\
\hline 19.9 & 26.9 & 0.05 & 0.4 & 31.2 & 0.7 & 0.6 & 54.7 \\
\hline 20.3 & 32.3 & 0.04 & 0.6 & 67.7 & 1.0 & 6.4 & 45.4 \\
\hline 8.7 & 15.5 & 0.03 & 0.2 & 63.8 & 0.4 & 3.1 & 17.8 \\
\hline 37.3 & 41.6 & 0.03 & 0.3 & 76.4 & 0.2 & 0.5 & 12.5 \\
\hline 23.3 & 28.5 & 0.03 & 0.1 & 72.8 & 0.6 & 2.1 & 12.4 \\
\hline 53.1 & 55.2 & 0.05 & 1.7 & 80.8 & 4.6 & 11.4 & 125.8 \\
\hline 30.0 & 23.7 & 0.03 & 0.1 & 65.8 & 0.9 & 0.2 & 8.0 \\
\hline
\end{tabular}

2. Social-fisheries contribute to societies by contributing to food security and creating employment (Allison et al. 2009; Barange et al. 2014). Thus, the social aspect was quantified using food security dependency calculated as: ( $\left.\frac{\text { fish protein intake / total animal protein intake }}{\text { totamal protein intake/required animal protein intake }}\right)$, the ratio of professional fisher population engaged in marine capture fisheries to total employees, and the percentage of small, i.e. non-industrial, or artisanal fishing vessels (by quantity) in each provincial fleet.

3. Economic_-fisheries contribute to economies by adding economic value and generating export income (Allison et al. 2009). Therefore, the economic aspect was represented using a composite index which included domestic marine catch as a percentage of GDP, per capita domestic marine catch, and the value of fisheries export as a $\%$ of total commodity export.

For each indicator, an average value in the most recent three years (from 2016 to 2018) was used to counter interannual variability. Variables were standardized based on their maximum values in our dataset and scaled within the range $0-1$ using the following conversion: $X / X_{\max }$. Biological, social, and economic indices were calculated as unweighted means of the standardized variables. Cluster analysis is one of the most efficient data processing methods for identifying homogeneous aggregates within a heterogeneous group (Wang et al. 2020; Kaufman and Rousseeuw 2009). The main advantage of cluster analysis is that it enables grouping based on common characteristics whilst discriminating among dissimilar groups to emphasize the differences among the clusters in accordance with the chosen variables. Its simplicity of application is also an advantage, especially when explaining the results to management decision-makers. In fisheries science, hierarchical cluster analysis is commonly employed for grouping observation units (Mahévas et al. 2008). To classify the varying challenges in the 11 fishing provinces, a hierarchical complete-linkage cluster analysis was then conducted based on Euclidean distance measure using the 'hclust' function in R software (https://stat.ethz.ch/R-manual/R-devel/library/stats/html/ hclust.html, accessed 7 Jan 2021). This function from the R software cluster package grouped the 11 fishing provinces based on biological, social, and economic attributes in the input dataset. Clustering is an agglomerative method that begins by treating each sample as a single cluster and, from there, begins to group the samples based on their similarity, as measured by their square Euclidian distance, until they form a large cluster. The smaller groups formed from the larger dataset are known as clusters. Grouping allows identification of similar observations that can potentially categorize them (Schimleck et al. 2020). The number of clusters was determined visually by the "best cut" height on the dendrogram where large changes in fusion levels were apparent (Mahévas et al. 2008). Using one-way analysis of variance (ANOVA), the reliability of clustering results was further verified by examining the statistically significant differences among cluster groups in the biological, social, and economic indices. 


\section{Results}

\section{Domestic marine catches, fishing effort, and catch per unit effort}

Domestic marine catches in China increased considerably over the past seven decades (Fig. 1). Specifically, total marine catches increased more than fourfold, from 1.48 million tons in 1961 to 3.87 million tons in 1985 , and then increased a further threefold to a peak of 12.03 million tons in 1999. Catches were subsequently stable at high levels with small fluctuations such that the catch was about 10.44 million tons in 2018.

The substantial increases in domestic marine catches were all accompanied by a sharp increase in fishing effort (Fig. 2). Fishing effort in China increased gradually with an initial increase from 0.25 million kilowatts in 1961 to 3.44 million kilowatts in 1985 , then it continued to increase to a peak of 12.33 million kilowatts in 2011. Fishing effort then decreased slightly in more recent years with 10.96 million kilowatts expended in 2018 (Fig. 1).

Domestic marine catches in Liaoning, Shandong, Guangdong, and Zhejiang increased exponentially and then slowed and plateaued during the late 1990s, although Zhejiang did not reach its peak catch until the mid-2010s. The first three provinces showed fishing effort continuing to peak for at least several years beyond their respective peak catches, indicating that these stocks were starting to become exploited beyond their maximum sustainable yields. Patterns were different for Hebei, Jiangsu, Fujian, and Guangxi provinces, with both catch and effort remaining relatively consistent throughout the development of the fisheries in these provinces. Tianjin and Shanghai provinces exhibited quite different patterns, with Tianjin peaking in the mid-1970s before falling away very rapidly, followed by a relatively consistent reduced catch and fluctuating effort until catches spiked in a second peak in 2012. Shanghai's catch peaked around 1978 and then declined along a steepening trajectory prior to leveling off from 2008 onwards. Effort remained elevated for many more years after the peak in catch, not reaching its maximum until 1991, and then from the early 2000s undergoing a steady decline (Fig. 2). In contrast, both the peak catch and effort in Hainan were reached only in more recent years. Among the 11 coastal provinces and municipalities, the provinces of Zhejiang, Shandong, Fujian, Guangdong, and Hainan accounted for approximately $83 \%$ of the total domestic marine catch in 2018 (Fig. 3). Table 2 lists the breakdown of domestic marine catch by fishing areas in the 11 fishing provinces of China in 2018.

Catch per unit effort (CPUE) in China decreased substantially during the 1960s to the 1980s. CPUE decreased from a peak of $5.97 \mathrm{t} / \mathrm{kW}$ in 1961 to $1.17 \mathrm{t} / \mathrm{kW}$ in 1981 , and subsequently remained at a low level (Fig. 4). Trends in CPUE in the 11 fishing provinces were consistent with the nationwide trend, which also showed a significant decrease and then stabilized at low levels (Fig. 4).

\section{Catch composition}

Collection of statistical data for fish species in China commenced in 1983. At the national scale, catch patterns among taxa were grossly similar, with invertebrates and algae mirroring the total catch of all species during 1983-2018 (Fig. 5). In contrast to the overall pattern, there were clear differences among provinces, especially Tianjin, Shanghai, and Hainan, in terms of both total catch and differences among taxa, such that the variation among taxa differed from one province to another, even for those provinces with
Fig. 1 Domestic marine catch and fishing effort in China during 1961-2018

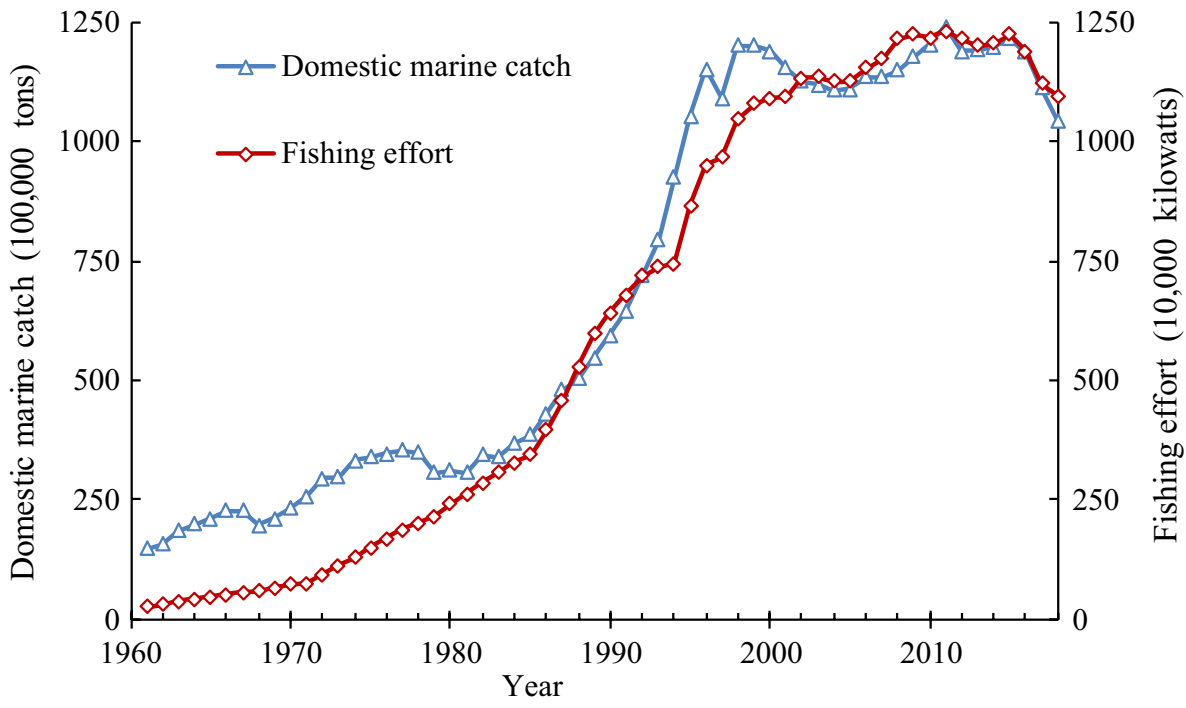



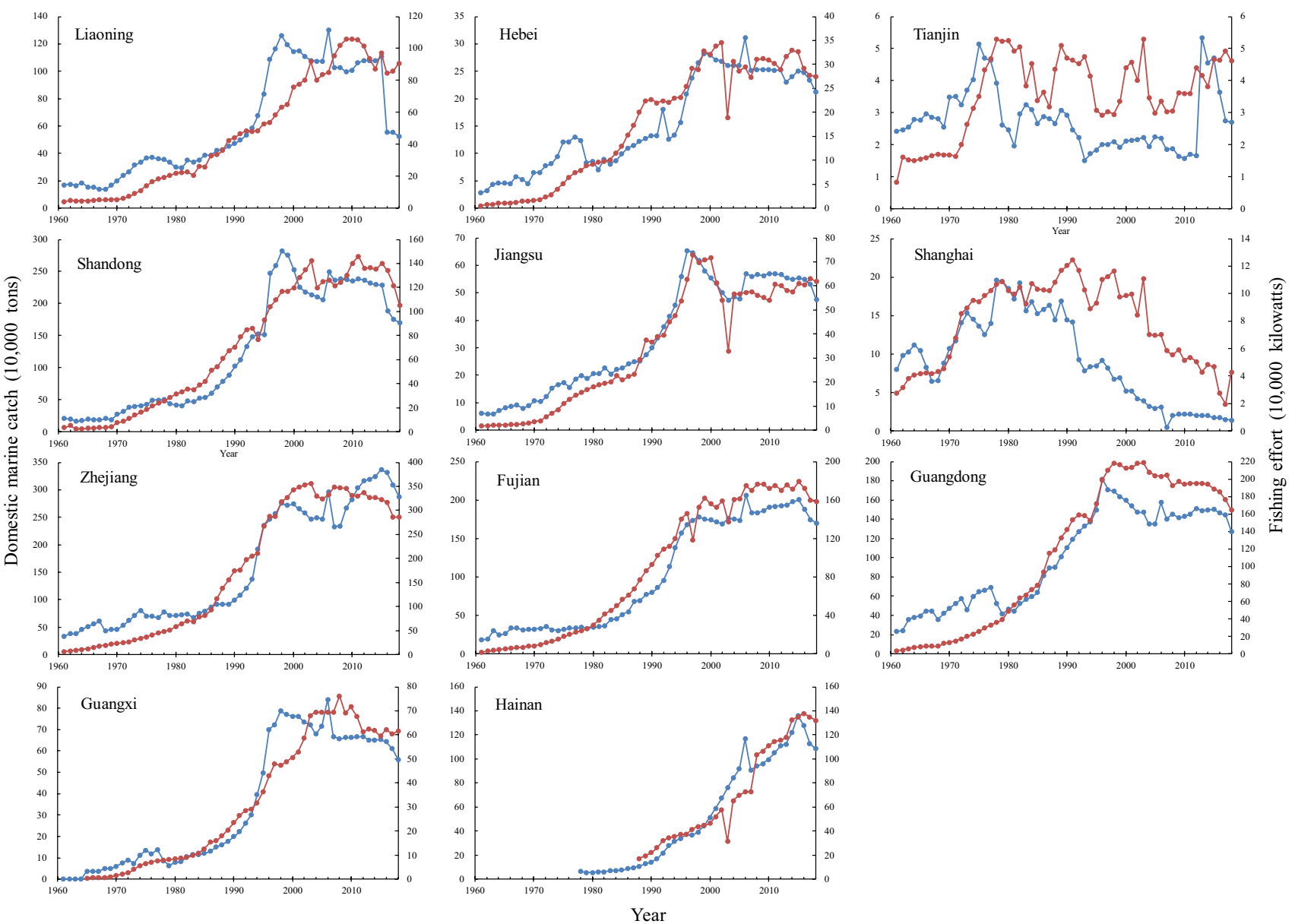

Fig. 2 Domestic marine catch and fishing effort in the 11 fishing provinces of China during 1961-2018 (blue line represents domestic marine catch. Red line represents fishing effort)

similar total catch patterns. Hainan showed a more prolonged and consistently linear increase during 1988-2018 prior to a downturn, mostly attributable to demersal species. In Liaoning, Hebei, Tianjin, Jiangsu, and Guangxi, invertebrates and algae dominated wild fisheries production. Pelagic species were as important as invertebrates in Shandong, Fujian, Guangdong, Guangxi, and Hainan (Fig. 5).

Catch percentage of fish species with $\mathrm{TL} \geq 3.5$, fish species with $\mathrm{TL}<3.5$, and invertebrates and algae were $30.1 \%$, $38.5 \%$, and $31.4 \%$, respectively, in 2018 . Nowadays low trophic level fish species make the largest contribution to marine catches in China. Table 1 lists the contribution of fish species with $\mathrm{TL} \geq 3.5$ to domestic marine capture fisheries in the 11 fishing provinces, and this ratio reached $50.7 \%$ and $41.8 \%$ in Hainan and Guangdong, respectively, in 2018.

\section{Main fish species}

The main fish species caught during 1983-2018 are shown in Fig. 6, with demersal fishes mainly including largehead hairtail Trichiurus lepturus, threadfin breams NEI Nemipterus spp., daggertooth pike conger Muraenesox cinereus, yellow croaker Larimichthys polyactis, filefishes NEI Cantherhines spp., porgies, seabreams NEI Sparidae, Soiny (redlip) mullet Liza haematocheilus, Groupers NEI Epinephelus spp., and large yellow croaker Larimichthys croceus, among which the catches of Trichiurus lepturus were far larger than the others and gradually decreased from 2010 onwards. Pelagic fishes mainly comprised Japanese anchovy Engraulis japonicus, scads NEI Decapterus spp., Pacific chub mackerel Scomber japonicus, seerfishes NEI Scomberomorus spp., silver pomfrets NEI Pampus spp., Japanese pilchard Sardinops melanostictus, pellona Ilisha spp., and Pacific herring Clupea pallasii, of which the catches of Japanese anchovy were highest but showed large annual fluctuations. Crustacean catches mainly comprised gazami crab Portunus trituberculatus, Akiami paste shrimp Acetes japonicus, southern rough shrimp Trachypenaeus curvirostris, fleshy prawn Penaeus chinensis, and blue swimming crab Portunus pelagicus, of which the catches of gazami 
Fig. 3 Breakdown of domestic marine catch by fishing provinces in China in 2018

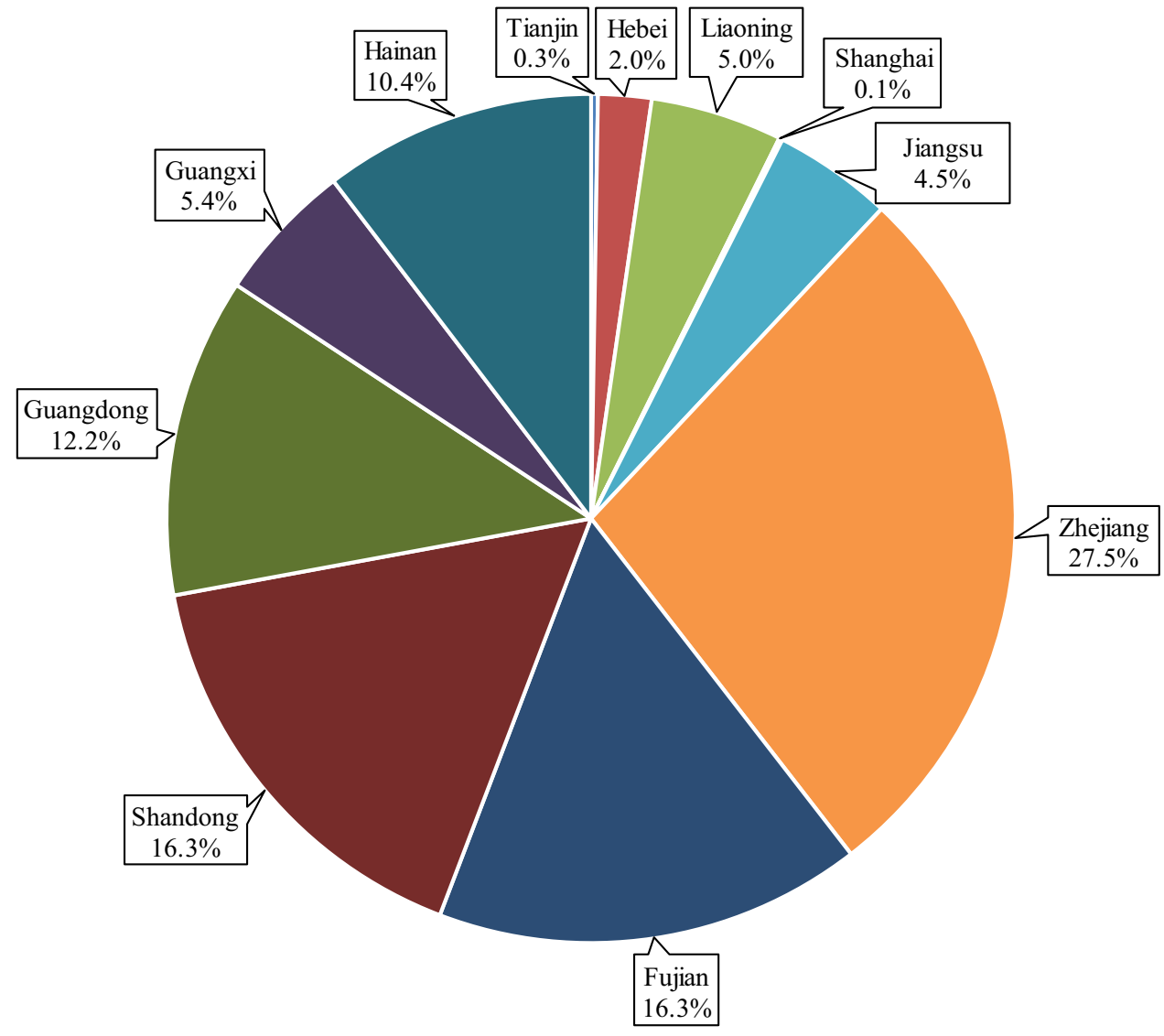

Table 2 Breakdown of domestic marine catch by fishing areas in the 11 fishing provinces of China in 2018

\begin{tabular}{lcclr}
\hline $\begin{array}{l}\text { Fishing prov- } \\
\text { inces }\end{array}$ & Bohai Sea/\% & Yellow Sea/\% & $\begin{array}{l}\text { East } \\
\text { China } \\
\text { Sea/\% }\end{array}$ & $\begin{array}{r}\text { South } \\
\text { China } \\
\text { Sea/\% }\end{array}$ \\
\hline Tianjin & 19.2 & 80.8 & & \\
Hebei & 77.0 & 23.0 & & \\
Liaoning & 38.5 & 60.4 & 1.1 & \\
Shanghai & & & 100 & \\
Jiangsu & 0.1 & 89.0 & 10.8 & 0.1 \\
Zhejiang & 4.8 & 5.4 & 89.4 & 0.4 \\
$\begin{array}{l}\text { Fujian } \\
\text { Shandong }\end{array}$ & 16.5 & 83.5 & 88.9 & 11.1 \\
Guangdong & & & & \\
Guangxi & & & 1.6 & 98.4 \\
Hainan & & & & 100.0 \\
Nationwide & 7.6 & 22.8 & 40.0 & 29.6 \\
\hline
\end{tabular}

crab, Akiami paste shrimp, and southern rough shrimp had all decreased slightly in recent years. The catches of fleshy prawn and blue swimming crab generally showed an increasing trend (Fig. 6).

Catches of the main target species including largehead hairtail, Japanese anchovy, gazami crab, and Akiami paste shrimp are shown in Fig. 7. Catches of largehead hairtail came mainly from Zhejiang, Guangdong, Fujian, and Hainan provinces, and the catch percentages in these four provinces were $41.3 \%, 13.6 \%, 14.8 \%$, and $13.7 \%$, respectively, in 2018. Of the 11 fishing provinces, Fujian, Guangdong, and Hainan were the only ones which showed a fluctuating upward trend in the catches of largehead hairtail, whereas this species decreased in all the other fishing provinces. Catches of Japanese anchovy were primarily obtained from Shandong Province, accounting for $61.2 \%$ of the total catch of Japanese anchovy in 2018. However, catches of Japanese anchovy in Shandong Province declined, with fluctuations following a peak catch in 2003. Gazami crab was mainly exploited by Zhejiang, Jiangsu, and Fujian provinces, accounting for $36.0 \%, 17.5 \%$, and $17.3 \%$ of the total catch of gazami crab in 2018. But catches of gazami crab have clearly decreased in each of these three provinces during the past four years. The provinces of Zhejiang, Fujian, Shandong, Liaoning, and Hebei were the main fishing provinces for Akiami paste shrimp, with catch percentage of $37.5 \%, 16.3 \%, 11.5 \%, 11.5 \%$, and $11.0 \%$, respectively, in 1983 . However, these respective values were $42.2 \%, 13.7 \%, 14.5 \%, 4.8 \%$, and $1.7 \%$ in 2018, with catches of Akiami paste shrimp significantly 

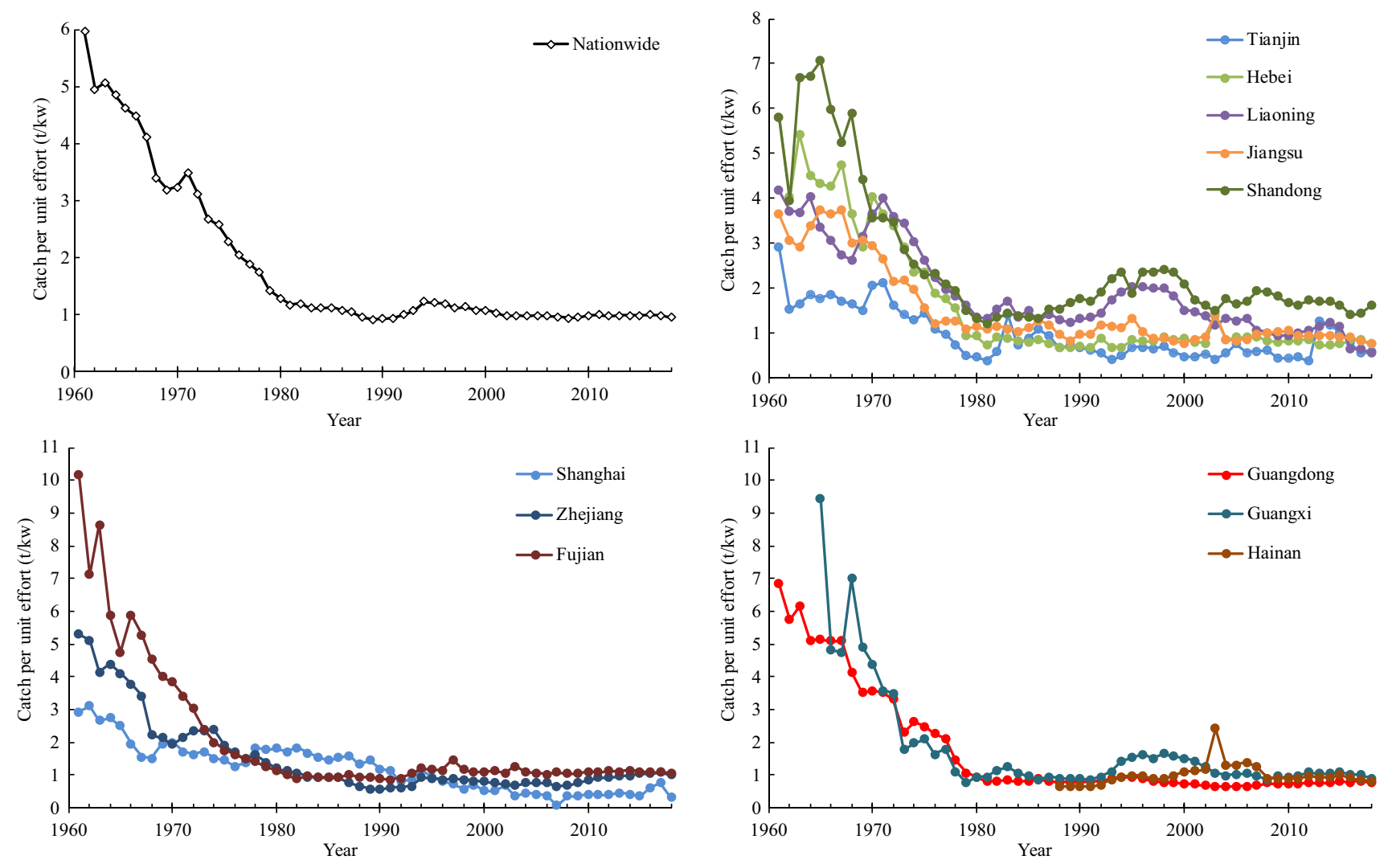

Fig. 4 Catch per unit effort (CPUE) of China and its 11 fishing provinces during 1961-2018

decreasing in Shandong, Liaoning, and Hebei provinces since the 2000s.

\section{Challenges faced by coastal provinces in China}

In terms of the biological aspect (Table 1), the catch percentage of fish species with $\mathrm{TL} \geq 3.5$ was highest in Hainan, followed by Guangdong and Fujian, and the bottom three provinces were Shanghai, Tianjin, and Hebei. Ranking of the catch percentage of demersal fishes was similar to that of the catch percentage of fish species with $T L \geq 3.5$. Specifically, Hainan and Guangdong ranked as the top two provinces, while Shanghai and Tianjin rank at the bottom of the list.

For the three indicators included in the social aspect, in terms of the proportion of small fishing vessels (by quantity), the ranking from high to low was Hainan, Guangdong, Guangxi, Liaoning, Fujian, Shandong, Hebei, Jiangsu, Zhejiang, Tianjin, and Shanghai provinces, with the proportions all higher than $50 \%$ in the first seven provinces. Food dependency was higher than the national level for all provinces except Shandong, Guangxi, and Hebei, with Hainan, Shanghai, and Fujian the top three provinces. Hainan and Fujian provinces had very high employment dependency, and the ratio of the professional fisher population engaged in marine capture fisheries to total employees in Hainan and
Fujian provinces reached $1.7 \%$ and $0.6 \%$, respectively, during 2016-2018, which was well above the national value of $0.1 \%$ (Table 1 ).

In terms of economics, Hainan, Fujian, Liaoning, and Shandong had very high seafood trade dependency. However, the values of fisheries exports as a percentage of total commodity export were much lower than the national level of $0.90 \%$ in Shanghai, Tianjin, Jiangsu, Guangdong, Hebei, and Zhejiang provinces. Nationwide, the value of domestic marine catch accounted for $0.2 \%$ of GDP during 2016-2018. However, this ratio reached 4.6\% in Hainan Province. In contrast, this proportion in Shanghai and Tianjin municipalities were only $0.02 \%$ and $0.07 \%$, respectively (Table 1).

A hierarchical cluster analysis was applied to group the 11 fishing provinces based on biological, social, and economic aspects (Fig. 8). Results showed that the 11 fishing provinces could be divided into four groups, and the biological, social, and economic indices differed significantly $(P<0.01)$ among cluster groups based on one-way ANOVA (Table 3). Specifically, Hainan Province belonged to one class, with the highest level of biological, social, and economic components. Fujian and Guangdong provinces belonged to another class, characterized by high levels of biological and social indices coupled with a middle-to-high level economic index. 

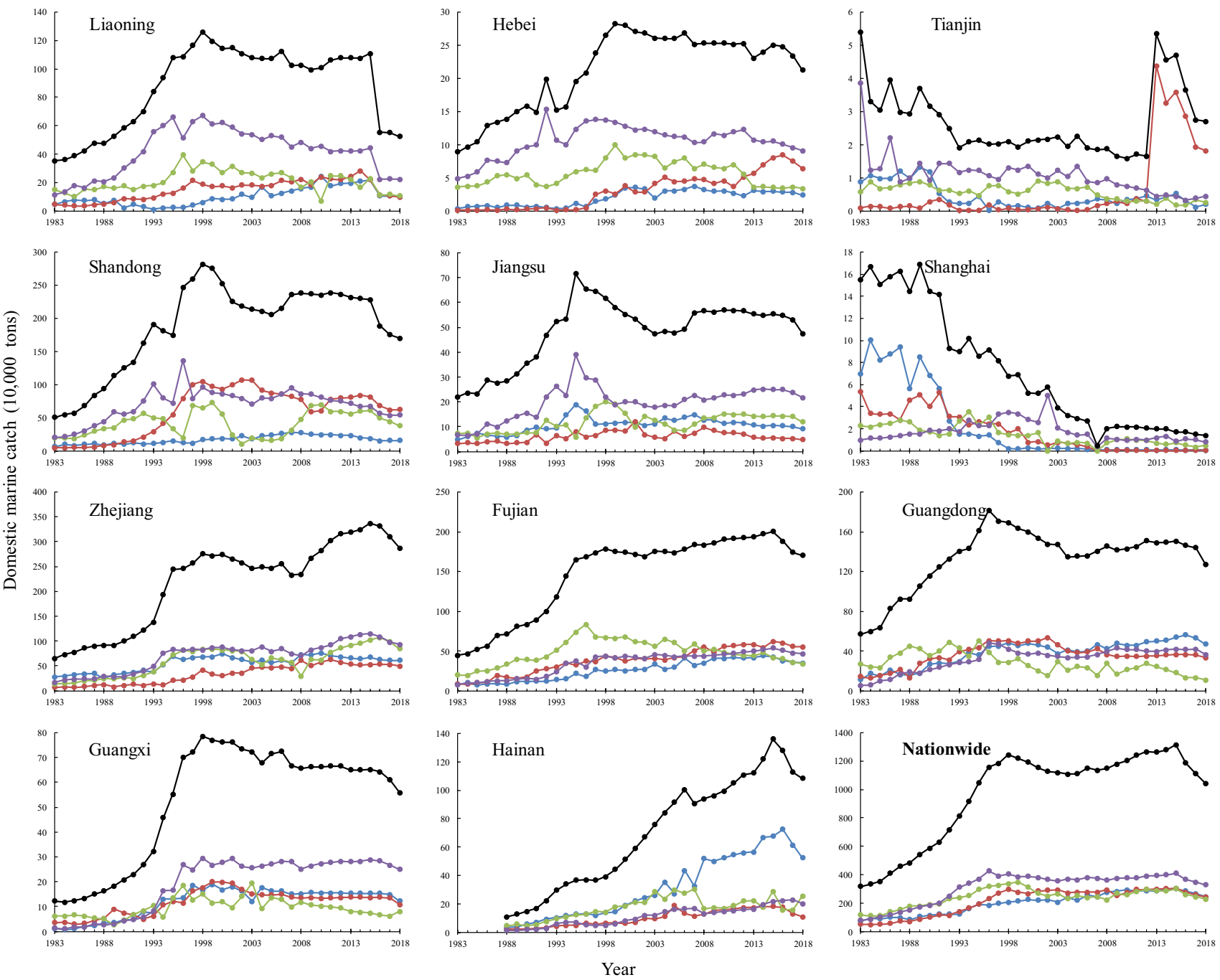

$\rightarrow$ Demersal fish $\rightarrow$-Pelagic fish $\rightarrow$ Other fish species $\rightarrow$ Invertebrates \& Algae $\rightarrow$ - Total

Fig. 5 Catch composition for 11 fishing provinces of China during 1983-2018

Zhejiang, Liaoning, Guangxi, Jiangsu, and Shandong provinces formed a third class with middle levels of biological, social, and economic components. Tianjin, Shanghai, and Hebei provinces represented the fourth class, which had low levels of these three components.

\section{Discussion}

China's 11 fishing provinces were grouped into four distinct clusters based on the analysis of the biological, social, and economic indicators we chose for this study. This illustrates the need to ensure that when planning for broadscale national implementation of fisheries management policies, the chosen management strategies are appropriately tailored to differences in situations that are unique to each province. Hainan Province showed itself to be the most socioeconomically dependent province with respect to its domestic fisheries production. Its high trophic level demersal species are currently the main targets, and fishing pressure persists at high levels. Actions need to be taken to strengthen both fisheries management and scientific stock assessments, to reduce the risk of overfishing and promote sustainable fisheries development in this province. Small vessels generally contribute more to numbers of jobs and community value of fisheries per ton than large-scale industrial fleets (Teh et al. 2019; Zeller et al. 2006). Given that fleets of small vessels operating at the local scale predominate in Hainan Province, boosting participation in recreational fisheries would not only contribute to fostering a new trend of coordinated development for the Hainan fisheries economy, but would also provide new employment opportunities for displaced traditional fishermen by utilizing their transferable skills of boating and fishing practices. 


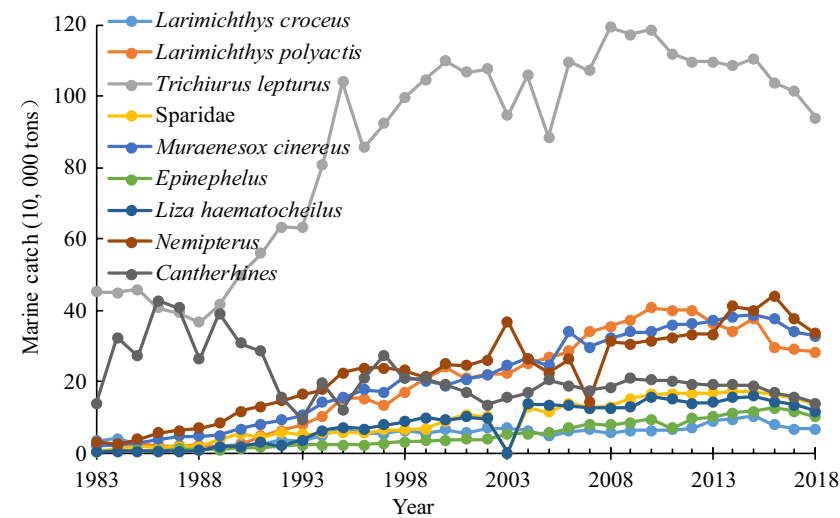

(a)

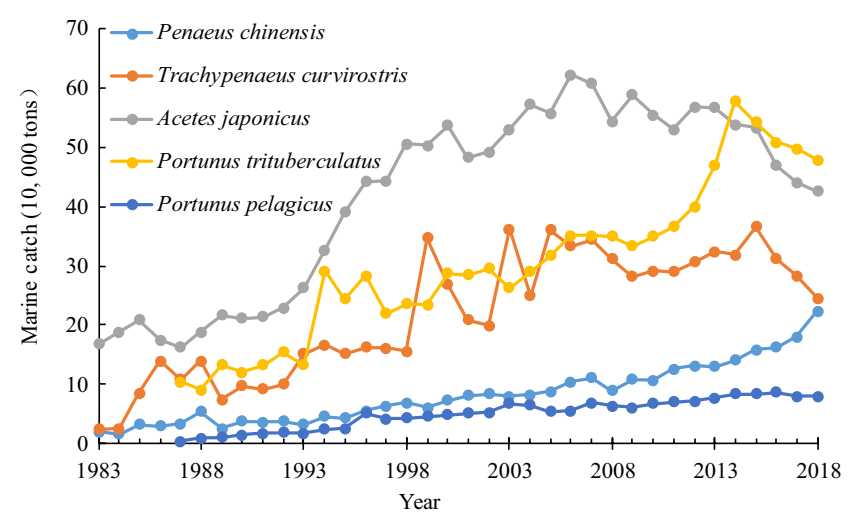

(c)

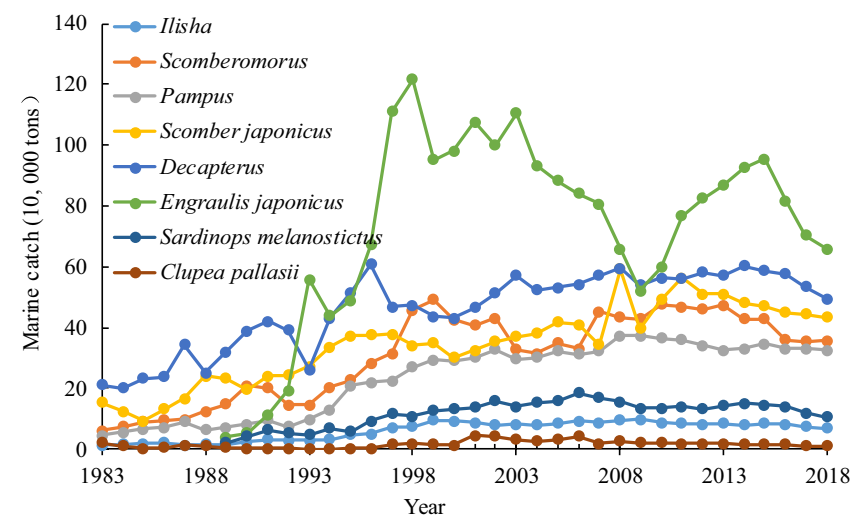

(b)

Fig. 6 Main species catches in China's marine capture fishery during 1983-2018, a demersal fishes; b pelagic fishes; c crustaceans

Fujian and Guangdong provinces belong to a second class in the cluster that is characterized by relatively good biological status and middle to high levels of socioeconomic dependency. Developing policies that promote environmentally friendly ocean farming and transferring fishermen out of the wild catch fishing industry are of paramount importance for decreasing the socioeconomic dependency in these two provinces. In addition, because economic dependency is much higher in Fujian Province, the government should actively implement measures to facilitate transformation and upgrading of its marine fishing industry.

Zhejiang, Liaoning, Guangxi, Jiangsu, and Shandong provinces had moderate dependence on marine capture fisheries, but invertebrate and pelagic species dominated the catch composition in these provinces. Therefore, there is an urgent need for a concerted effort not only to meet this cluster's socioeconomic requirements, but also to constrain marine fishing effort and restore fish stocks. As the top two provinces in terms of domestic marine catches, Zhejiang and Shandong should strengthen their efforts to promote the integration and coordinated development of primary, secondary, and tertiary industries such as traditional fishing, processing, recreational angling, and aquatic leisure services.
Tianjin, Shanghai, and Hebei provinces have had low dependence on marine capture fisheries, and traditional demersal fish stocks were overfished in these areas. Sustainable practices such as constraining fishing effort, increasing habitat protection, and restoring degraded habitats, along with marine stock enhancement, should be further explored to restore fish stocks and increase yields. Aquaculture is considered to be an effective way to increase food supplies and promote economic development, and it currently plays a significant role in fish supply in Tianjin and Hebei provinces. Promoting eco-farming models that combine traditional and modern practices by positively extending eco-farming technology and mitigating pollution associated with aquaculture are approaches that hold promise for achieving sustainable fisheries development.

China's marine fishing industry has expanded dramatically over the past seven decades, and the country now leads the world in marine capture fisheries (Aksnes and Browman 2015; FAO 2018; Fu et al. 2018). However, the accelerating harvest and lack of effective implementation of fisheries management have resulted in a reduction in the biomass of traditional high-value species and a change in the structure of marine ecosystems (He et al. 2015; Liang 


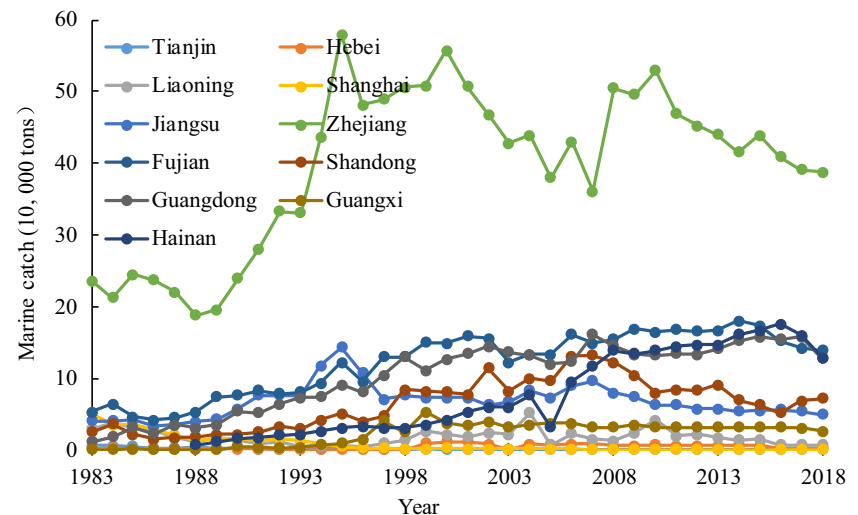

(a)

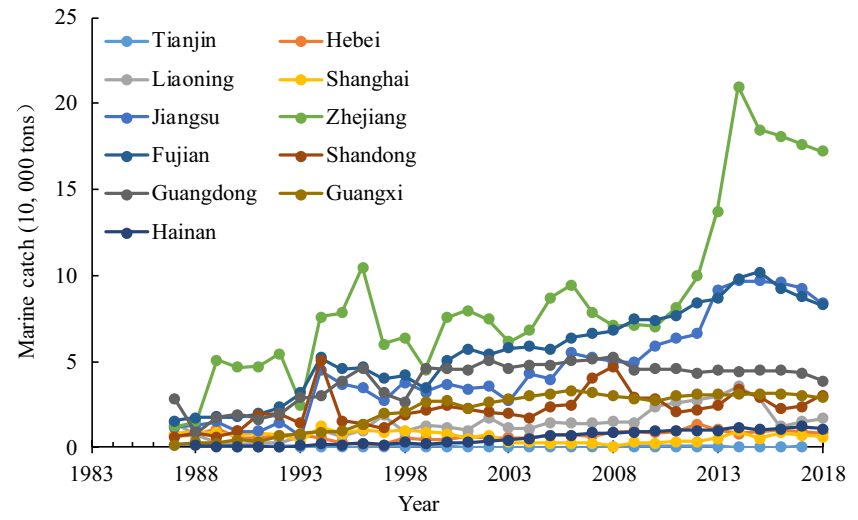

(c)

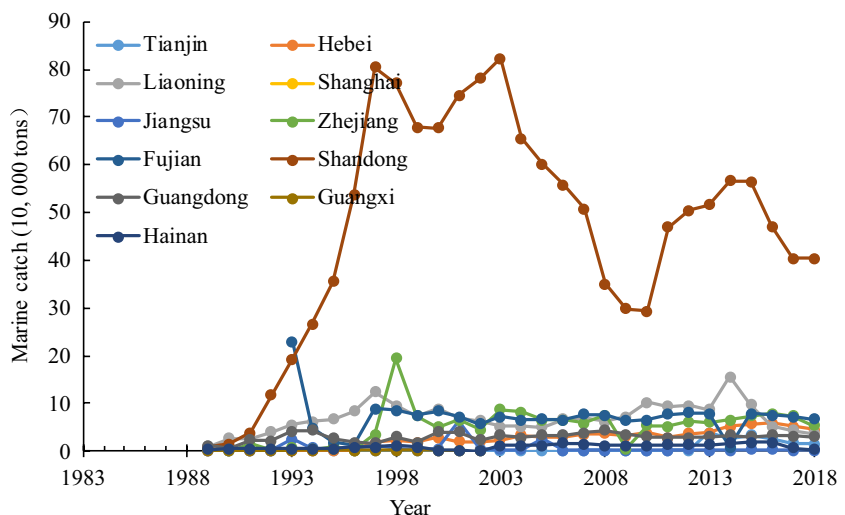

(b)

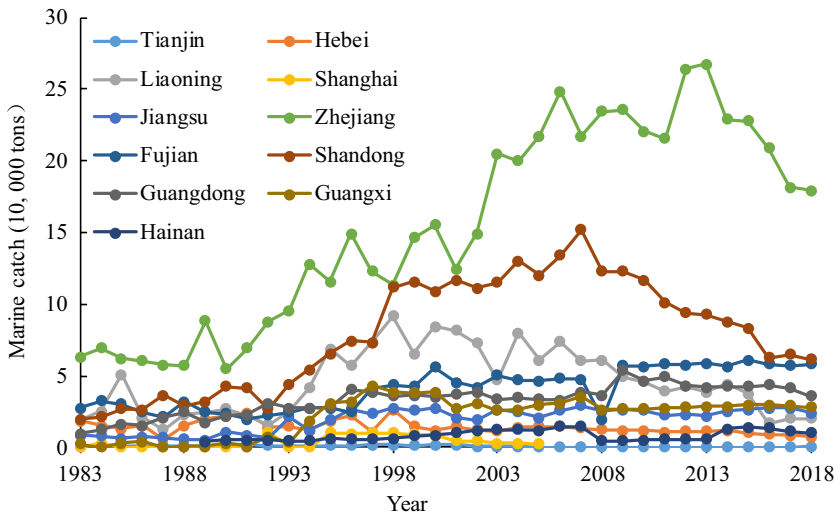

(d)

Fig. 7 Catches of four main species for 11 fishing provinces of China during 1983-2018, a Trichiurus lepturus; b Engraulis japonicus; c Portunus trituberculatus; $\mathbf{d}$ Acetes japonicus

Fig. 8 Dendrogram of an analysis of fisheries biological, social, and economic indices for each of China's 11 provinces, based on Euclidean distance using the complete linkage method for hierarchical clustering of the provinces

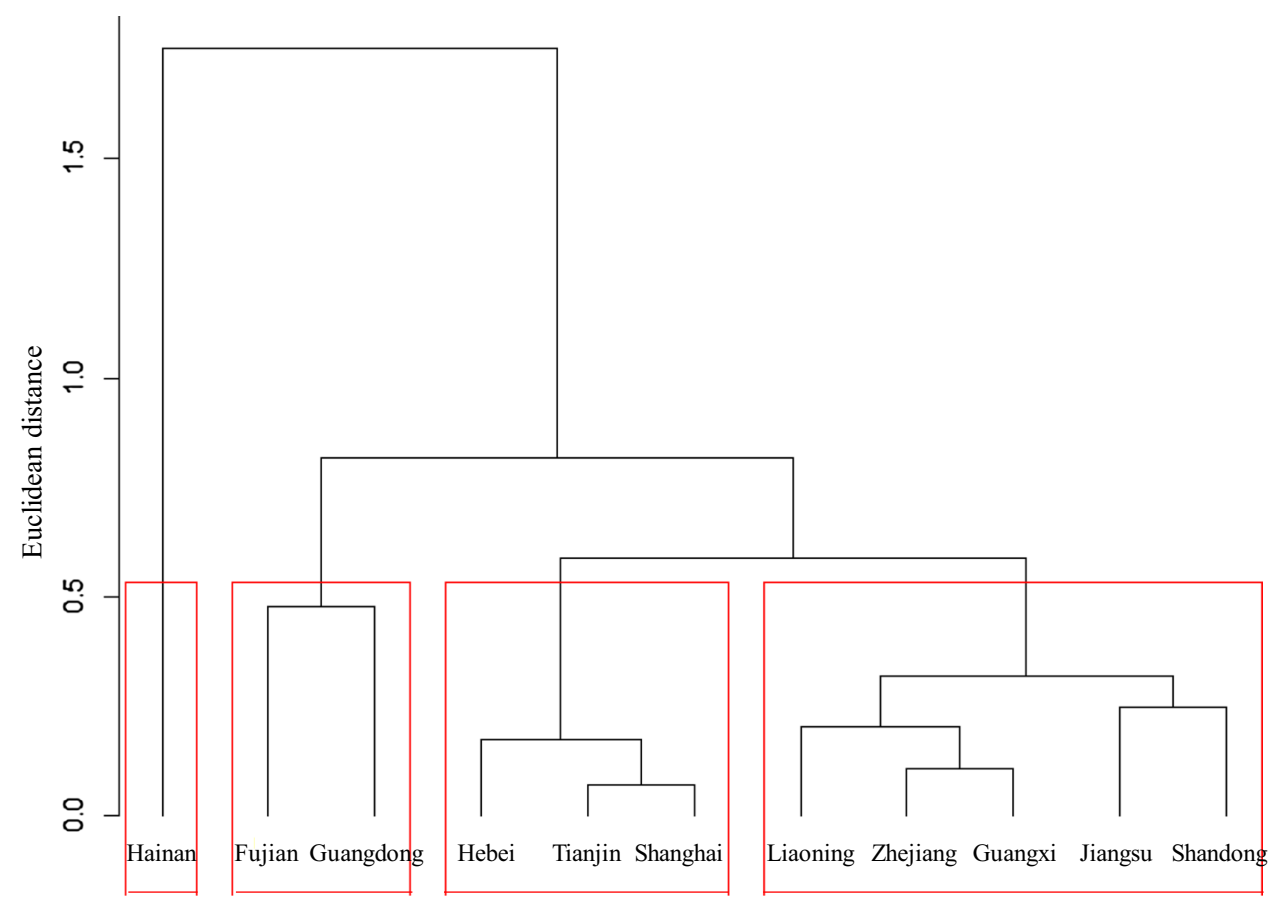


Table 3 Results of one-way ANOVA

\begin{tabular}{llll}
\hline & Biological index & Social index & Economic index \\
\hline$F$ value & 19.9 & 31.5 & 22.7 \\
$P$ value & 0.0008 & 0.0002 & 0.0006 \\
\hline
\end{tabular}

and Pauly 2017; Jin 2004; Liu 2019). As would be expected, the intensive fisheries exploitation has resulted in significant drops in catch per unit effort at the both national and provincial scales. Excess fishing capacity has been identified as a major impediment to effective fisheries management in China (Blomeyer et al. 2012; Cheng et al. 2006; Huang and Tang 2019).

Marine capture fisheries in China are multi-gear and multi-species ( $\mathrm{Li}$ et al. 2017). Invertebrate and pelagic species are now the largest contributors to marine catches in China at the national scale, and this is reflected within most of the fishing provinces. The intense exploitation of marine fisheries resources also has significantly changed the structure of fisheries production in China (Mallory 2013; FAO 2020). Production has shifted from capture fisheries to the current situation where about three quarters of the country's fish production is derived from aquaculture. Among the 11 fishing provinces in China, aquaculture production accounted for more than $70 \%$ of the total fish production, except for Shanghai, Zhejiang, and Hainan provinces (Fisheries Bureau of the Ministry of Agriculture and Rural Affairs 2019). Capture fisheries have shifted from domestic fisheries to distant-water fisheries in Shanghai, specifically, the distant-water fishing contributes $58 \%$ of total fish production but the ratio of domestic marine catches is only 5\% in 2018 (Fisheries Bureau of the Ministry of Agriculture and Rural Affairs 2019).

Total biological allowable catch is around 9 million tons in China (Han 2018; Yang et al. 2016; Yue et al. 2017). However, domestic marine catches have exceeded biologically allowable limits since the mid-1990s. Therefore, intensive exploitation has exceeded the reproduction and regeneration capacity of marine fishery resources for many years. Fisheries resources are now under enormous pressure from the high levels of fishing efforts, while fishing practices in China are largely indiscriminate, with trawl fisheries producing $47 \%$ of total domestic marine catches, which may have negative effects on biodiversity and populations of individual species (Szuwalski et al. 2017; Hiddink et al. 2011). What is worse, large numbers of fishermen are actually intensifying the exploitation level of fishery resources (Han 2018; Huang and He 2019).

Although the reliability of domestic marine capture fisheries production statistical information in China has been widely challenged for over-reporting (Pauly et al. 2014), the statistical data collection systems in China were designed carefully and the Chinese government has conducted three national agricultural censuses to improve data reliability throughout the time series since 1997. Problems of overcapacity and depleted fisheries stocks still pose a serious threat to marine ecosystems in China (Chen et al. 2018; Lindkvist et al. 2008; Tang 2018). Nowadays, China has placed particular emphasis on eco-civilization, which aims to "build a resource-saving and environment-friendly society based on environmental carrying capacity of resources, the laws of nature, and sustainable development" (Cao et al. 2017; Fisheries Administration Bureau 2014; State Council Web: http://www.gov.cn/guowuyuan/2015-09/21/content_ 2936327.htm Accessed 1 August 2019). The Chinese concept of eco-civilization is quite similar to the more widely used concept of sustainable development. The bio-socioeconomic indicators used in this study highlight not only the serious biological status and socioeconomic importance of domestic marine capture fisheries in China, but also the challenges China is facing from overfishing. Nationwide, to promote sustainable fisheries in China, the following three aspects should be further strengthened. First, it will remain necessary in the short to medium term to further promote alternative employment opportunities for the existing cohort of commercial fishers considering the current high social dependence of their communities on fisheries. Fish processing industries and recreational fisheries are promising mechanisms for job transferability among fishermen whilst increasing the sustainability of seafood production. Second, fisheries resources in China are much like the commons, which have the characteristics of competitiveness and public accessibility. A property rights system which would limit participation has not yet been implemented. Common-pool resources place challenges on society because of a mismatch between public and private interests (Epstein et al. 2018; Finus et al. 2020). Using rights-based approaches such as assigning secure and enforceable harvesting rights to individuals or groups (for example, individual transferable quotas, ITQ) can provide incentives for sustainable use of fisheries resources. Third, with the depletion of marine fisheries resources, sustainable and environmentally friendly aquaculture is recommended to meet the increasing demand for fish protein whilst alleviating the pressure on wild stocks. Development of modern marine ranching in particular can help in optimizing the overall structure of the seafood production industry in China.

Our study has shown that cluster analysis is useful in classifying the grouped data according to their similarities and extracting useful summarized information (Castillo et al. 2016; Pulver et al. 2016; Wang et al. 2020). The challenge for future assessments of this kind is to expand the acquisition of different kinds of data at the provincial scale to support a broader range of metrics. 
Acknowledgements This work was supported by the National Key R\&D Program of China (Grant no. 2017YFE0104400), the National Natural Science Foundation of China (Grant no. 31872692), the Special Funds for Taishan Scholars Project of Shandong Province, the Innovation Team of Fishery Resources and Ecology in the Yellow Sea and Bohai Sea (2020TD01).

Open Access This article is licensed under a Creative Commons Attribution 4.0 International License, which permits use, sharing, adaptation, distribution and reproduction in any medium or format, as long as you give appropriate credit to the original author(s) and the source, provide a link to the Creative Commons licence, and indicate if changes were made. The images or other third party material in this article are included in the article's Creative Commons licence, unless indicated otherwise in a credit line to the material. If material is not included in the article's Creative Commons licence and your intended use is not permitted by statutory regulation or exceeds the permitted use, you will need to obtain permission directly from the copyright holder. To view a copy of this licence, visit http://creativecommons.org/licenses/by/4.0/.

\section{References}

Aksnes DW, Browman HI (2015) An overview of global research effort in fisheries science. ICES J Mar Sci 73:1004-1011

Allison EH, Perry AL, Badjeck MC, Adger WN, Brown K, Conway D, Halls AS, Pilling GM, Reynolds JD, Andrew NL, Dulvy NK (2009) Vulnerability of national economies to the impacts of climate change on fisheries. Fish Fish 10:173-196

Barange M, Merino G, Blanchard JL, Scholtens J, Harle J, Allison EH, Allen JI, Holt J, Jennings S (2014) Impacts of climate change on marine ecosystem production in societies dependent on fisheries. Nat Clim Change 4:211-216

Blomeyer R, Goulding I, Pauly D, Sanz A, Stobberup A (2012) The role of China in world fisheries. In: Directorate-General for Internal Policies. Policy Department B: Structural and Cohesion Policies, Brussels, EU

Cao L, Chen Y, Dong S, Hanson A, Huang B, Leadbitter D, Little DC, Pikitch EK, Qiu Y, Mitcheson YS, Sumaila UR, Williams M, Xue G, Ye Y, Zhang W, Zhou Y, Zhuang P, Naylor RL (2017) Opportunity for marine fisheries reform in China. Proc Natl Acad Sci USA 114:435-442

Castillo TI, Baigún CRM, Minotti PG (2016) Assessment of a fisheries legal framework for potential development of an ecosystem approach to fisheries management in large rivers. Fisheries Manag Ecol 23:510-518

Chen Q, Shen W, Yu B (2018) Assessing the vulnerability of marine fisheries in China: towards an inter-provincial perspective. Sustainability 10:4302

Cheng J, Cai W, Cheung W, Pitcher TJ, Liu Y (2006) An estimation of compliance of the fisheries of China with Article 7 (fisheries management) of the UN code of conduct for responsible fishing, 22 pages in T. J. Pitcher, D. Kalikoski, and G. Pramod (eds) Evaluations of compliance with the UN code of conduct for responsible fisheries. Fisheries Centre Research Reports, p 1191

Epstein G, Andrews E, Armitage D, Foley P, Pittman J, Brushett R (2018) Human dimensions of ecosystem-based management: lessons in managing trade-offs from the Northern Shrimp Fishery in Northern Peninsula, Newfoundland. Mar Policy 97:10-17

FAO (2018) The state of world fisheries and aquaculture 2018 - meeting the sustainable development goals. Rome

FAO (2020) The state of world fisheries and aquaculture 2020-sustainability in action. Rome
Finus M, Schneider R, Pintassilgo P (2020) The role of social and technical excludability for the success of impure public good and common pool agreements: the case of international fisheries. Resour Energy Econ 59:101122

Fisheries Administration Bureau (2014) Ways of strengthening fisheries: corpus of promoting modern fishery. China Agriculture Press, Beijing

Fisheries Bureau of the Ministry of Agriculture and Rural Affairs (1999) China fisheries statistical yearbook 1999. China Agricultural Press, Beijing

Fisheries Bureau of the Ministry of Agriculture and Rural Affairs (2006) China fisheries statistical yearbook 2006. China Agricultural Press, Beijing

Fisheries Bureau of the Ministry of Agriculture and Rural Affairs (2018) China fisheries statistical yearbook 2018. China Agricultural Press, Beijing

Fisheries Bureau of the Ministry of Agriculture and Rural Affairs (2019) China fisheries statistical yearbook 2019. China Agricultural Press, Beijing

Fu X, Zhang M, Liu Y, Shao C, Hu Y, Wang X, Su L, Wang N, Wang C (2018) Protective exploitation of marine bioresources in China. Ocean Coast Manag 163:192-204

Garcia SM, Rosenberg AA (2010) Food security and marine capture fisheries: characteristics, trends, drivers and future perspectives. Philos Trans R Soc B Biol Sci 365(1554):2869-2880

Han Y (2018) Marine fishery resources management and policy adjustment in China since 1949. Chin Rural Econ 9:14-28

He Q, Bertness MD, Bruno JF, Li B, Chen G, Coverdale TC, Altieri AH, Bai J, Sun T, Pennings SC, Liu J, Ehrlich PR, Cui B (2015) Economic development and coastal ecosystem change in China. Sci Rep 4:5995-5995

Hiddink JG, Johnson AF, Kingham R, Hinz H (2011) Could our fisheries be more productive? Indirect negative effects of bottom trawl fisheries on fish condition. J Appl Ecol 48:1441-1449

Huang S, He Y (2019) Management of China's capture fisheries: review and prospect. Aquac Fish 4:173-182

Huang S, Tang Y (2019) Review and prospect of theories of fisheries management and China's practice. J Fish China 43:211-231

Jin X (2004) Long-term changes in fish community structure in the Bohai Sea, China. Estuar Coast Shelf Sci 59:163-171

Jin X, Dou S, Shan X, Wang Z, Wan R, Bian X (2015) Hot spots of frontiers in the research of sustainable yield of Chinese inshore fishery. Prog Fish Sci 36:124-131

Kang B, Liu M, Huang X, Li J, Yan Y, Han C, Chen S (2018) Fisheries in Chinese seas: what can we learn from controversial official fisheries statistics. Rev Fish Biol Fish 28:503-519

Kaufman L, Rousseeuw PJ (2009) Finding groups in data: an introduction to cluster analysis, vol 344. Wiley

Li J, Cao K, Ding F, Yang WB, Shen GM, Li Y (2017) Changes in trophic-level structure of the main fish species caught by China and their relationship with fishing method. J Fish Sci China 24:109-119

Li B, Jin X, Yang J (2019) Spatio-temporal evolution and influencing factors for marine fisheries industry ecosystem vulnerability in China. Acta Ecol Sin 12:4273-4283

Liang C, Pauly D (2017) Growth and mortality of exploited fishes in China's coastal seas and their uses for yield-per-recruit analyses. J Appl Ichthyol 33:746-756

Liang S, Qin M (2014) Stochastic frontier analysis on Chinese inshore capture fishery-based on provincial panel data. J Agrotech Econ $8: 118-127$

Lindkvist KB, Trondsen T, Xie J (2008) Restructuring the Chinese seafood industry, global challenges and policy implications. Mar Policy 32:432-441

Liu Z (2019) Research on the status, causes and governance of marine fishing ground desertification. Issues Agric Econ 6:105-116 
Liu M, De Mitcheson YS (2008) Profile of a fishery collapse: why mariculture failed to save the large yellow croaker. Fish Fish 9:219-242

Lou D, Gu S, Zhong S (2005) Current situation and development trend of marine industry in China. Resour Sci 27:20-26

Mahévas S, Bellanger L, Trenkel VM (2008) Cluster analysis of linear model coefficients under contiguity constraints for identifying spatial and temporal fishing effort patterns. Fish Res 93:29-38

Mallory TG (2013) China's distant water fishing industry: evolving policies and implications. Mar Policy 38:99-108

Mallory TG (2016) Fisheries subsidies in China: quantitative and qualitative assessment of policy coherence and effectiveness. Mar Policy 68:74-82

National Bureau of Statistics of China (2019) China statistical yearbook 2019. China Statistics Press, Beijing

Normile D (2017) China cracks down on coastal fisheries. Science 356:573

Pauly D, Belhabib D, Blomeyer R, Cheung W, Cisneros-Montemayor AM, Copeland D, Harper S, Lam VWY, Mai Y, Manach FL, Österblom H, Mok KM, Meer L, Sanz A, Shon S, Sumaila UR, Swartz W, Watson R, Zhai Y, Zeller D (2014) China's distantwater fisheries in the 21st century. Fish Fish 15:474-488

Pulver JR, Liu H, Scott-Denton E (2016) Modelling community structure and species co-occurrence using fishery observer data. ICES J Mar Sci 73:1750-1763

Schimleck L, Matos JL, Higa A, Trianoski R, Prata JG, Dahlen J (2020) Classifying wood properties of loblolly pine grown in Southern Brazil using NIR-hyperspectral imaging. Forests 11:686

Shen G, Heino M (2014) An overview of marine fisheries management in China. Mar Policy 44:265-272

Su S, Tang Y, Chang B, Zhu W, Chen Y (2020) Evolution of marine fisheries management in China from 1949 to 2019: how did China get here and where does China go next. Fish Fish 21:435-452

Sun K, Zhou X, Su Z, Zhang H (2016) Dynamic assessment and spatial differentiation of sustainable utilization of marine fishery resources in China. Scientia Geographica Sinica 36:1172-1179

Szuwalski CS, Burgess MG, Costello C, Gaines SD (2017) High fishery catches through trophic cascades in China. P Natl Acad Sci USA 114:717-721

Szuwalski CS, Jin X, Shan X, Clavelle T (2020) Marine seafood production via intense exploitation and cultivation in China: costs, benefits, and risks. PLoS ONE 15:1-30

Tang Q (2018) Fisheries science knowledge system and characteristic China approach for fisheries development. J Agric 8:19-23

Tang Q, Ying Y, Wu Q (2016) The biomass yields and management challenges for the Yellow sea large marine ecosystem. Environ Dev 17:175-181
Teh LSL, Witter A, Cheung W, Sumaila UR, Yin X (2017) What is at stake? Status and threats to South China Sea marine fisheries. Ambio 46:57-72

Teh LSL, Cashion T, Alava JJ, Cheung W, Sumaila UR (2019) Status, trends, and the future of fisheries in the East and South China Seas. Fisheries Centre Research Reports

Wang Z, Shi J (2015) Research on China's marine fishery resources protection and optimal allocation. Chin Fish Econ 33:66-73

Wang S, Liu H, Pu H, Yang H (2020) Spatial disparity and hierarchical cluster analysis of final energy consumption in China. Energy 197:117195

$\mathrm{Xu} \mathrm{H}$ (2013) The growth of the production of China's marine fishing industry under the condition of resource recession - an empirical analysis based on the 1956-2011 fisheries data. J Shandong Univ (Philos Soc Sci) 5:86-93

Yang H, Xing L, Zhang L (2016) Promoting systematic design and innovation-driven development for modern fishery. Bull Chin Acad Sci 12:1339-1346

Yu H, Yu Y (2008) Fishing capacity management in China: theoretic and practical perspectives. Mar Policy 32:351-359

Yue D, Wang L, Zhu X, Geng R, Fang H, Xiong M, Wang Q, Zhou Y, Li X (2017) Problems and countermeasures in the supply side of marine capture fishery in China. J Agric Sci Technol 7:17-26

Zeller D, Booth S, Pauly D (2006) Fisheries contributions to the gross domestic product: underestimating small-scale fisheries in the Pacific. Mar Resour Econ 21:355-374

Zhang H (2016) Chinese fishermen in disputed waters: not quite a "people's war." Mar Policy 68:65-73

Zhang H (2018) Fisheries cooperation in the South China Sea: evaluating the options. Mar Policy 89:67-76

Zhang W, Liu M, Sadovy de Mitcheson Y, Cao L, Leadbitter D, Newton R, Little DC, Li S, Yang Y, Chen X, Zhou W (2020) Fishing for feed in China: facts, impacts and implications. Fish Fish 21:47-62

Zhong Y, Power G (1997) Fisheries in China: progress, problems, and prospects. Can J Fish Aquat Sci 54:224-238

Publisher's Note Springer Nature remains neutral with regard to jurisdictional claims in published maps and institutional affiliations. 